\title{
THE CORRELATION BETWEEN HUMAN CAPITAL AND GROSS ADDED VALUE IN THE BIOECONOMY SECTORS AT THE EUROPEAN UNION (EU) COUNTRY LEVEL
}

\author{
Associate Professor Olimpia Neagu, PhD
}

"Vasile Goldiş" Western University of Arad, Romania E-mail: olimpian2005@yahoo.com

Professor Florin Dumiter", PhD

"Vasile Goldiş" Western University of Arad, Romania E-mail: fdumiter@yahoo.com

Associate Professor Alexandra Braica, PhD

"Vasile Goldiș" Western University of Arad, Romania E-mail: alexandra.braica@gmail.com

\author{
Assistant Professor Ștefania Jimon ${ }^{12}$, PhD Student \\ "'Vasile Goldiș" Western University of Arad, Romania \\ 2,"Lucian Blaga" University of Sibiu, Romania \\ E-mail: jimonstefania@yahoo.com
}

Associate Professor Gabriela David, PhD

"Vasile Goldiş" Western University of Arad, Romania

E-mail: dvd_gbr@yahoo.com

(Received: October 2018: Accepted: January 2019; Published: March 2019)

\begin{abstract}
The paper aims to prove the link between human capital and gross added value in bioeconomy sectors in the EU countries. Data from EUROSTAT data base regarding employment and gross added value in 6 bioeconomy sectors were used in a cross-country regression analysis. The econometric analysis of cross-country data shows a positive correlation between human capital in bioeconomy sectors and their gross output in 2015 in 26 European countries. It is found also that the correlation is stronger in the highly developed economies as in the central-eastern countries, as well as in the European economy.
\end{abstract}

Keywords: competencies, green economy, smart economy, development.

JEL Codes: Q20, Q57, M10, M12.

* Corresponding author: Florin Dumiter. E-mail:fdumiter@yahoo.com

$S$ sciendo Studia Universitatis "Vasile Goldis" Arad. Economics Series Vol 29 Issue 1/2019 ISSN: 1584-2339; (online) ISSN: $2285-3065$ 


\section{Introduction}

The notion of human capital has gradually developed beginning within the observation of Adam Smith (1776) according to which the acquisition of personal skills and talents are used in economic processes.

At first, the human capital is defined as a result of education through which were developed some competences, abilities and skills (Schultz, 1961; Becker, 1975; Nelson \& Winter, 1982; Coleman, 1988), but nowadays, human capital is considered to be more than cognitive abilities and incorporates all characteristics of an individual, both the cognitive ones and also the un - cognitive ones, intra personals and inter - personals. Thereby, the personal experiences, creativity, motivation, the temperament, emotional intelligence and health status are considered as a component part of human capital (Tomer, 1999; Leliaert et. al., 2003; Luthans et. al., 2004; OECD, 2011).

In the official document Readiness for the Future of Production Report 2018 (World Economic Forum, 2018), human capital reveals himself as a determinant factor of socio - economic development. Technical development and technological innovation generates new challenges vis - á - vis of labor market, also requiring the acquirement of new skills from human capital perspective.

Also, beside technological development, in the last decade it is noted an increased interest given to bioeconomy and to promote the green and smart economy (European Commission, 2011). Worldwide it can be noticed a convergence oriented towards the optimization of economic processes for an efficient utilization of increasingly limited resources.

The usage of knowledge regarding the cellular processes, integration of biomass and biotechnology in developing new products will produce significant changes in global economy in the future, being necessary the adaptation at the new requirements of labor market.

It can be notice, therefore, an obviously link between the quality of human capital, bio-economy and sustainable economic development. Roth (2017) argues the impact and costs of pollution on educational level, and implicitly on human capital formation. The results of the researches made by the author above mentioned attract the attention to the fact that air pollution leads to scholar absenteeism, and forward, to diminished quality of human capital by limited knowledge, abilities and skills, consequences that will restrict the accessibility on labor market.

Therefore, in the new era of biotechnology and digitalization, the success is given by the diversified abilities and transversal skills development (Anderson, 2017).

In this article, we tackle the connection between human capital and gross added 
value in the bioeconomy sectors in the UE country level. The paper is constructed by the following manner: in the starting part of the article the introduction represents a veritable caveat regarding the asessment of human capital importance and it's impact upon bio economy; in the second section we have enacted the literature review, within a veritable quid pro quo between human capital and bioeconomy; the third section represents the author's contribution throughout highlighting the nexus or connection between human capital and gross added value, especially throughut modelling the correlation between these two variables in the UE member states. In the final part of the article we present the concluding remarks of the empirical study with the presumed scientific impact upon the relevant literature in this field, meanwhile the apendix will reveal some important features for the fulfillment of the econometrical tests within additional tehnical specification.

\section{Literature review}

\subsection{Human capital}

Moses Abramovitz (1956) notices and describes an existing gap regarding the capacity of traditional production factors to lead the complete economic growth, fact which points out to the aim of existing knowledge, skills and personal abilities in the labor market.

Therefore, Mincer (1958) considers that the accumulation of knowledge and experiences through education will lead in future to greater benefits. A recent study about sustained economic growth in China shows that educational politics and the quality of education act had beneficial effects on national labor market and will maintain the economic growth in the next 20 years ( $\mathrm{Li}$ et. al., 2017). This fact is also noted in other studies referring to the aim of education in development and economic growth (Lafuente \& Rabetino, 2011; Neagu, 2012; Pribac \& Anghelina, 2015; Massingham and Tam, 2015).

Together with education, Schultz (1961) appreciates that medical status has an important role in economic development. Policies to reduce malnutrition and the findings of new methods on prevention, diagnostics and therapies, had determined the life quality improvement and the mortality decrease, which led to increased work productivity (Goldin, 2016).

Because of the augment of social protection systems and medical services, appeared modifications in the structure of population. In member states of European Union it can be notice the increased life expectancy and the decrease of natality, reality which from the human capital perspective has to be looked as an 
Neagu, O., Dumiter, F., Braica, A., Jimon, Ş., David, G. (2019)

The correlation between human capital and gross added value in the bioeconomy sectors at the European Union (EU) country level

accumulation of human capital with knowledge and rich experience, useful to create economic value (Goldin, 2016).

Schultz's outlook is developed by Becker (1975) who considers that all cost made for the development and protection of human capital represents' investments from which future benefits will be earned. This concept is also sustained by Kucharčíková \& Mičiak (2017), which highlight the fact that the value of an enterprise is given by the investments in human capital, regarded as an intangible and untraded asset, a "shadow" asset which "should be treated as part of a person's endowed wealth" (Chen et. al., 2006, pp.104).

\subsection{Bioeconomy}

Bioeconomy appears as a form of maintaining the durable economic development in the context of limited quantitative and qualitative resources, changes of the climate conditions and environmental degradation. Concrete, through bioeconomy is understood the efficient and effective usage of natural resources (European Commission, 2012; Scarlat et. al, 2015), which according to Mazza \& ten Brink (2012) are economic assets crucial for the economic growth process.

The objective of bioeconomy is to promote the usage of renewal biologic resources and alternative sources of energy as inputs in technological processes (Pfau, et. al., 2014; Kleinschmit et. al., 2014; Bugge et. al., 2016). In this purpose, bioeconomy is interconnected with green economy to conserve the environment, and also with circular economy to reduce the scraps and wastes from economic processes (Ollikainen, 2014; Szekacs, 2017). Even if these three domains take action on three different directions, the final aim of these is environmental protection and socio economic development (D'Amato et. al., 2017).

Although bioeconomy is the oldest branch of economy, the importance given to this significantly rise after 2000 , at the moment being a new standard in sustainable development (Ipate et. al., 2015) due to promotion of sustainable use of existing resources (Schimd, Padel \& Levidow, 2012).

European Commission (2012), in the official document of Innovating for Sustainable Growth: a Bioeconomy for Europe establishes the strategy to promote bioeconomy in the community, the main directions being: food security, natural resources sustainability, diminishing climate changes, maintaining competitiveness and creating jobs. McCormick \& Kautto (2013) draw the attention on the necessity of a sustained common effort from government, industrial sector and population to ensure the success of this step.

A study made in 2014 analyses the progress of bioeconomy in European Union and the impact of socio - economic, legislative, technological and marketing impact. In

\footnotetext{
4 Studia Universitatis "Vasile Goldis" Arad. Economics Series Vol 29 Issue 1/2019 $S$ sciendo ISSN: 1584-2339; (online) ISSN: 2285 - 3065

Web: publicatii.uvvg.ro/index.php/studiaeconomia. Pages $1-20$
} 
Neagu, O., Dumiter, F., Braica, A., Jimon, Ş., David, G. (2019)

The correlation between human capital and gross added value in the bioeconomy sectors at the European Union (EU) country level

this study, there are identified the challenges crossed and proposed in three main directions of action regarding the development of bioeconomy: investments in research, innovation and new skills acquirement; involvement and interaction between decision factors and other stakeholders; development of market competitiveness (Ten Pierick et. al., 2010; M'Barek et. al., 2014).

According to Padel et. al. (2010), bioeconomy gives a safety degree due to protection and efficient use of resources, and thanks to the development of new forms of economic activities, this determines a growth of added value and contributes to income redistribution. On the other hand, has to be given attention to the risk that may come and also to the ethical problems implied (Hilgartner, 2007; IRGC, 2008).

Ronzon et. al. (2017) proposes the quantification of bioeconomy in European Union starting from the turnover value and the number of employees in this sector. The empirical results show up that the largest share of bioeconomy sectors are productive, the greatest success being recorded into agricultural sector and food, drinks and tobacco industry. It had been recorded similarities and differences between countries, useful to build and develop new strategies to promote bioeconomy on a country level.

By developing new processes and products, bioeconomy is an innovative field which ensures sustainable development and produces socio - economic added value. To accomplish these aims, it is necessary a multidisciplinary approach which reunify the domains of economics, technical and technological, biological, social and human capital development throughout acquiring the adequate competencies that can satisfy the requirements existing on the labor market.

\section{Metodology and empirical data}

The paper used data extracted from Eurostat for the 28 EU Member States in 2015. Within the analysis, 26 EU countries are considered; Luxembourg and Malta were excluded due to the lack of data. We considered the number of employees (thousand) in the bioeconomy sectors as a proxy variable for human capital. The dependent variable is the gross added value (GVA), measured in million Eur. (current prices) created in 6 bioeconomy sectors: Agriculture, Forestry, Fishing and aquaculture, Manufacture of food, beverages and tobaco, Manufacture of wood and Manufacture of paper.

We estimate the dependency between GAV and EMPL through the following regression equation:

$$
G V A_{i s}=\alpha+\beta \cdot E M P L_{i s}+u_{i s}, \quad \mathrm{i}=1, . .26, \mathrm{~s}=1, . ., 6
$$


Neagu, O., Dumiter, F., Braica, A., Jimon, S., David, G. (2019)

The correlation between human capital and gross added value in the bioeconomy sectors at the European Union (EU) country level

where: i denotes the country, s denotes the sector and $u_{i s}$ is the error term.

$$
u_{i s}=\mu_{i}+v_{i s}
$$

$\mu_{i}$ denotes the unobservable country specific effect and $v_{i s}$ is the disturbance related to differences between bioeconomy sectors within countries.

We assume that there are two possible econometric models: (1) fixed effect model (FE) - where the variation across countries can be correlated with the independent variable (employment) and the effects of bioeconomy sectors are not taken into consideration and (2) random effects model (RE) - where the variation across countries is random and uncorrelated with the independent variable (see Hsiao, 2002).

We chose the appropriate model by using the Hausman test (see Clark and Linzer, 2012):

$$
H=\left(\hat{\beta}_{R E}-\hat{\beta}_{F E}\right)^{\prime}\left[\operatorname{Var}\left(\hat{\beta}_{F E}\right)-\operatorname{Var}\left(\hat{\beta}_{R E}\right)\right]^{-1}\left(\hat{\beta}_{R E}-\hat{\beta}_{F E}\right)
$$

$\mathrm{H}$ denotes the chi-square distribution with degree of freedom equals to the number of regressors in the model.

In the case of no correlation between independent variable and country effects, the estimates of $\beta$ in fixed effects model ( $\hat{\beta}_{F E}$ ) should be similar to the estimation of $\beta$ in random effects model $\left(\hat{\beta}_{R E}\right)$. The null hypothesis presumes that the random effects model is appropriate.

When $p$ is less than 0.05 (the conventional level of significance), the null hypothesis is rejected in the favour of the fixed effects model. In the opposite case, when the Hausman test does not indicate a significant difference ( $p>0.05)$, the null hypothesis is accepted meaning that the random effects model is appropriate (see Clark and Linzer, 2012).

In order to carry out the econometric analysis the STATA 13.1 software was used.

\section{Empirical results}

The results of the estimation of equation 1 in the two models (fixed - effects and random - effects) are exposed in Table 1.

\footnotetext{
6 Studia Universitatis "Vasile Goldis" Arad. Economics Series Vol 29 Issue 1/2019 $S$ sciendo ISSN: 1584-2339; (online) ISSN: $2285-3065$

Web: publicatii.uvvg.ro/index.php/studiaeconomia. Pages $1-20$
} 
Neagu, O., Dumiter, F., Braica, A., Jimon, S., David, G. (2019)

The correlation between human capital and gross added value in the bioeconomy sectors at the European Union (EU) country level

Table 1 Fixed-effects and Random-effects model

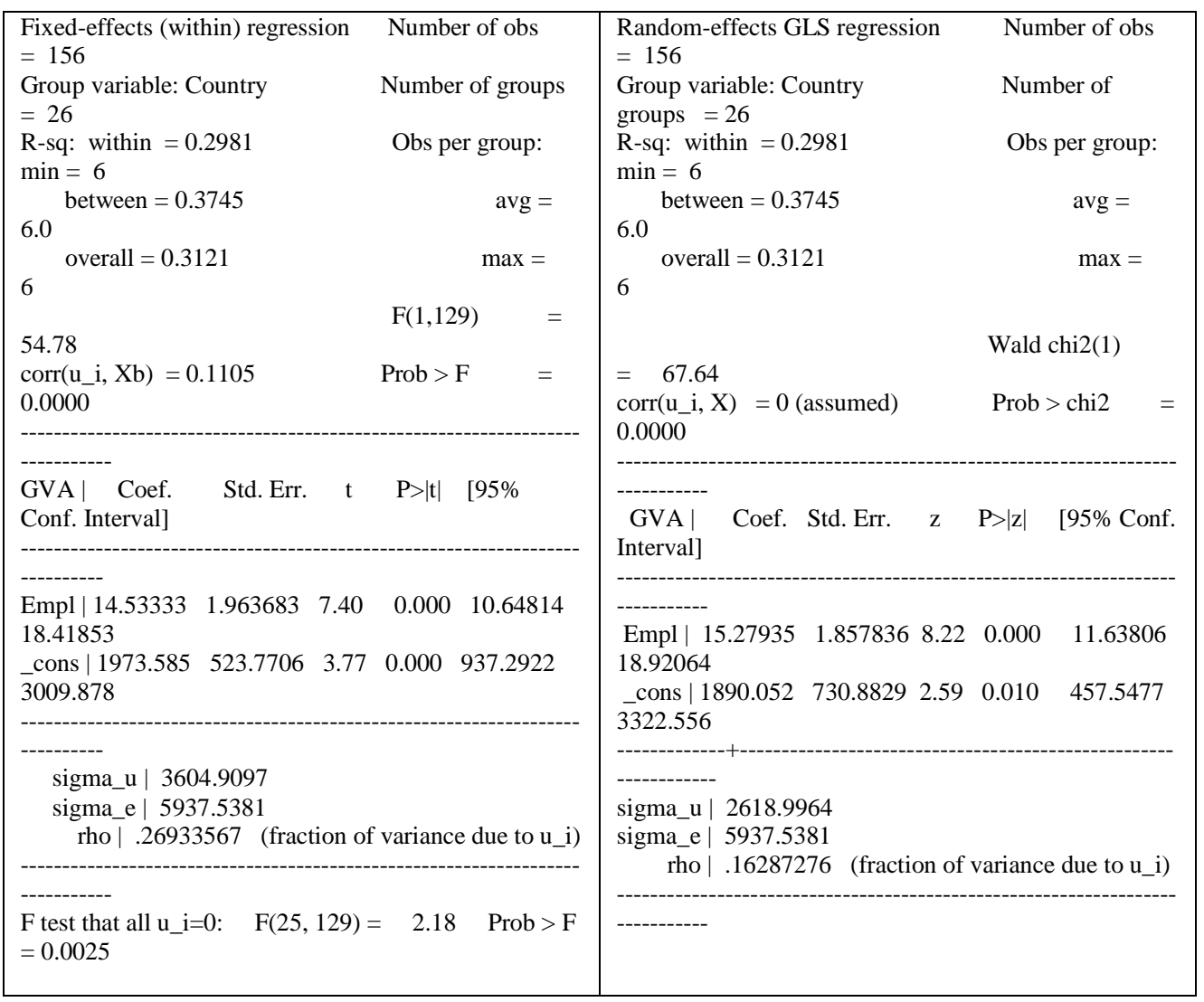

Source: authors' computation using STATA 13.1 software.

We use the Hausman test in order to select the apropriate model (Table 2). 


\section{Table 2 Hausman test}

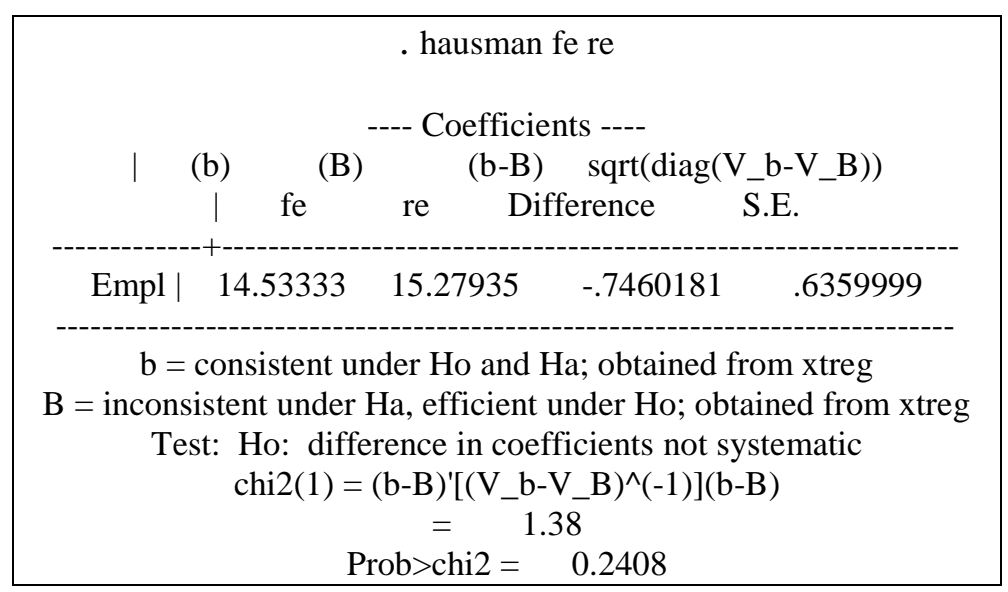

Source: authors' own computation using STATA 13.1 software.

Due to the fact that the value of Probchi2 is 0.2408 higher than 0.05 (the significance level) the Ho hypothesis is accepted and the random - effects (RE) model is selected (Table 1).

According to the data displayed in Table 1, the estimated equation 1 is the following:

$$
\begin{array}{cl}
G V A_{i s}=1890.052+15.27935 \cdot \mathrm{Empl}_{\text {is }} \\
(0.01) & (0.000) \\
(730.8829) & (1.857836)
\end{array}
$$

In this equation the value of $\mathrm{P}$ for the constant term (1890.052) is $0.01<0.05$. For the coefficient of the variable Empl, the value of $\mathrm{P}$ is $0.000<0.05$. The model can be statistically validated, as a whole, a for a significance threshold of $5 \%$, due to the fact that Prob is $0.000<0.05$ (Table 1).

The estimated robust standard errors are reported in the Table 3.

Due to the fact that Prob and P are lower than 0.05 the model can be validated. We notice also, that the estimates of coefficients and errors in Table 3 are the same as those produced by the command xtreg re. 
Neagu, O., Dumiter, F., Braica, A., Jimon, S., David, G. (2019)

The correlation between human capital and gross added value in the bioeconomy sectors at the European Union (EU) country level

After running the tests of heteroskedasticity across panels, autocorrelation within panels and correlation across panel by using the command xtgls in Stata (with the options: panels (hetero), panels (correlated), panels (hetero) corr, panels (hetero) corr (ar1), panels (hetero) corr (psar1),panels (iid) corr (psar1)) we noticed that (see Apendix):

- in all cases the value of Prob was lower than 0.05;

- the variance of each of the panels differs, the presence of heteroskedasticity

being identified;

- the correlation parameter is unique for each panel;

- there is no correlation across panels;

- the errors within panels are independent;

- in each panel the AR1 process is similar.

Table 3 Estimates of robust standard errors

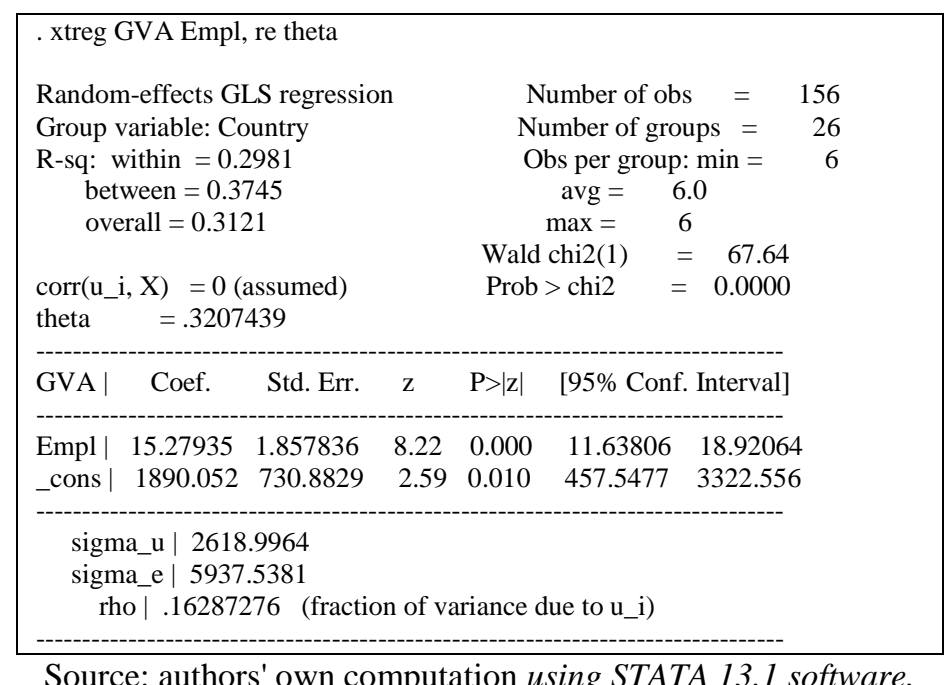

According to the above analysis, the active human capital in the bioeconomy sectors expressed by the number of employees has a positive statistically validated influence on the gross output of these sectors in 26 European economies. When the number of employees increases with one unit, the increase of GVA is of 15.27935 units.

Presuming that there are significant differences between western and eastern central European economies affecting the analysis, we run the regression equation 
Neagu, O., Dumiter, F., Braica, A., Jimon, Ş., David, G. (2019)

The correlation between human capital and gross added value in the bioeconomy sectors at the European Union (EU) country level

1 by spliting in two the 26 economies: the group of 15 high developed economies (Belgium, Cyprus, Germany, Italy, France, Spain, Greece, Netherland, Denmark, Finland, Austria, Portugal, Ireland, Sweden, United Kingdom) and the group of 11 developing countries (Bulgaria, Croatia, Czech Republic, Estonia, Lithuania, Latvia, Hungary, Poland, Slovenia, Slovakia, Romania).

Through running the Hausman test, we choose the random effects model for the group of western countries and the fixed effects model for the eastern - central European countries. Table 4 reports the estimations of equation 1 for the two groups of countries. Due to the fact that Prob and P are lower than 0.05 the model can be validated. We notice also, that the estimates of coefficients and errors in Table 3 are the same as those produced by the command xtreg re.

After running the tests of heteroskedasticity across panels, autocorrelation within panels and correlation across panel by using the command xtgls in Stata (with the options: panels (hetero), panels (correlated), panels (hetero) corr, panels (hetero) corr (arl), panels (hetero) corr (psarl),panels (iid) corr (psarl)) we noticed that (see Apendix):

- in all cases the value of Prob was lower than 0.05;

- the variance of each of the panels differs, the presence of heteroskedasticity being identified;

- the correlation parameter is unique for each panel;

- there is no correlation across panels;

- the errors within panels are independent;

- in each panel the AR1 process is similar.

According to the above analysis, the active human capital in the bioeconomy sectors expressed by the number of employees has a positive statistically validated influence on the gross output of these sectors in 26 European economies. When the number of employees increases with one unit, the increase of GVA is of 15.27935 units.

Presuming that there are significant differences between western and eastern central European economies affecting the analysis, we run the regression equation 1 by spliting in two the 26 economies: the group of 15 high developed economies (Belgium, Cyprus, Germany, Italy, France, Spain, Greece, Netherland, Denmark, Finland, Austria, Portugal, Ireland, Sweden, United Kingdom) and the group of 11 developing countries (Bulgaria, Croatia, Czech Republic, Estonia, Lithuania, Latvia, Hungary, Poland, Slovenia, Slovakia, Romania).

Through running the Hausman test, we choose the random effects model for the group of western countries and the fixed effects model for the eastern - central European countries. Table 4 reports the estimations of equation 1 for the two groups of countries. 
Neagu, O., Dumiter, F., Braica, A., Jimon, S., David, G. (2019)

The correlation between human capital and gross added value in the bioeconomy sectors at the European Union (EU) country level

Table 4 Results of estimation of equation 1 in high developed and developing European countries

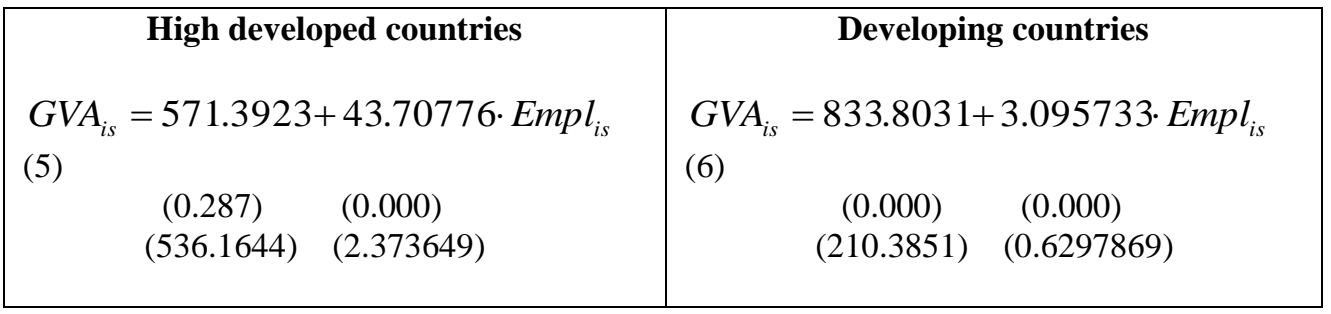

Source: authors' own computation using STATA 13.1 software.

We estimate the standard robust errors in both cases (Table 4) and notice that the estimates of coefficients and errors are the same as those initially estimated (Table 3). The FE model is validated in all its components due to the fact that $p$ - values for constant and Empl are lower than 0.05 as well as the value of Prob. The RE model can be statistically validated as a whole and we notice that the constant is not significant (the $\mathrm{p}$ - value for constant is higher than 0.05 ).

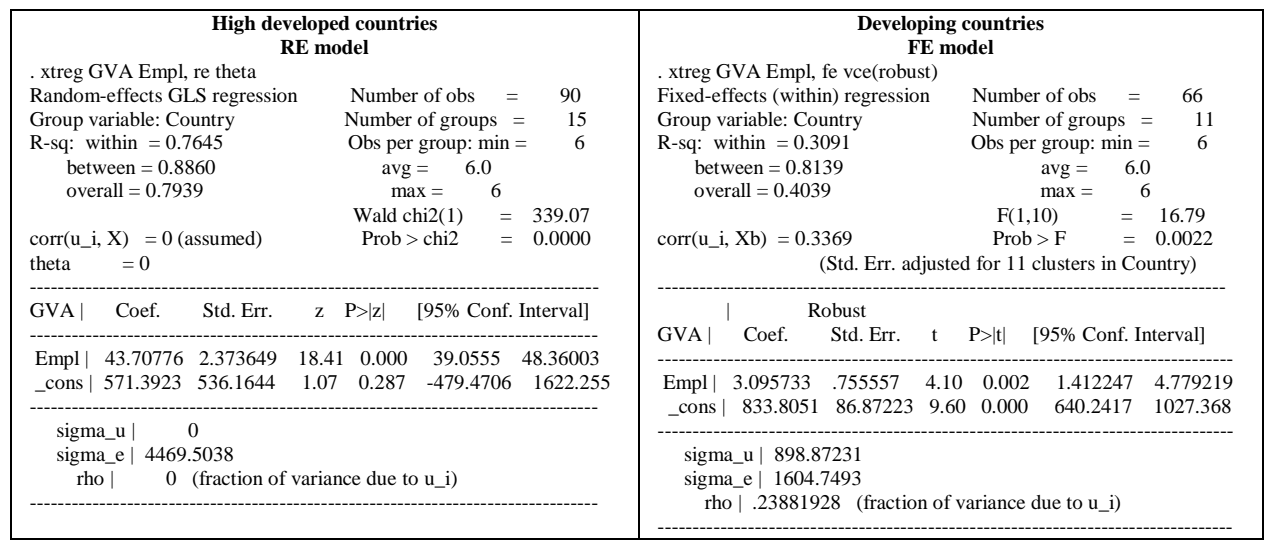

Source: authors' own computation using STATA 13.1 software.

The results of all tests run for the RE model are reported in the section $\mathrm{B}$ of the Appendix. They are similar to those obtained for the group of 26 European countries (presence of heteroskedasticity, unique correlation parameter for each panel, independent errors within panels, similar AR1 in each panel).

By comparing the estimated equations 4,5 and 6 , we notice that the effect of

$S$ sciendo Studia Universitatis "Vasile Goldis" Arad. Economics Series Vol 29 Issue 1/2019 
Neagu, O., Dumiter, F., Braica, A., Jimon, Ş., David, G. (2019)

The correlation between human capital and gross added value in the bioeconomy sectors at the European Union (EU) country level

human capital on the output of bioeconomy sectors is higher in the 15 high developed countries as in the group of 26 as well as in the group of the 11 eastern central European economies. When the number of employees increases with one unit, the increase in GVA is with 43.708776 units, almost twice than in the whole European economy ( 25 countries) and of 14.3 times higher than in the European developing economies.

\section{Conclusions}

Through an econometrical analysis of cross - country panel data we found a positive correlation between human capital and gross economic output in 6 bioeconomy sectors within 26 European economies.

We found also that the correlation between human capital and gross output in the bioeconomy sectors is stronger in the highly developed economies as in the central - eastern countries, as well as in the European economy. Possible explanations of these findings could consist in differences in the quality of human capital (skills, knowledge, health, and working conditions), labour productivity, investment in these sectors, or public policies aiming to stimulate their development. Indeed, based on EUROSTAT data, the labour productivity as gross added value per employee in bioeconomy sectors calculated for 2015 has values in a range from 14.7 thousand Euro to 158.5 thousand Euro in high developed countries (Finland) and from 2,4 thousand Euro to 14.1 thousand Euro in developing countries (Bulgaria), meaning a work efficiency of 5.65 to 11.24 times lower in eastern central European countries.

Further studies are needed to describe and explain these differences and to identify the sources and factors driving the growth of bioeconomy sectors in these countries.

\section{Acknowledgements}

The authors thank the anonymous reviewers and editor for their valuable contribution.

\section{Funding}

This research received no specific grant from any funding agency in the public, commercial, or not - for - profit sectors.

\section{Author Contributions}

ON and FCD conceived the study and were responsible for the design and development of the data analysis. $\mathrm{AB}$ and $\mathrm{SJ}$ were responsible for data collection and

12 S sciendo

Studia Universitatis "Vasile Goldis" Arad. Economics Series Vol 29 Issue 1/2019 ISSN: 1584-2339; (online) ISSN: 2285 - 3065

Web: publicatii.uvvg.ro/index.php/studiaeconomia. Pages $1-20$ 
Neagu, O., Dumiter, F., Braica, A., Jimon, S., David, G. (2019)

The correlation between human capital and gross added value in the bioeconomy sectors at the European Union (EU) country level

analysis and also for data interpretation. GD was responsible for the literature review section.

\section{Disclosure Statement}

The authors have not any competing financial, professional, or personal interests from other parties.

\section{References}

1. Abramovitz, M., (1956), Resouce and output trends in the United States since 1870. American Economic Review. 56-9226, 5-23.

2. Anderson, K.A., (2017), Skill networks and measures of complex human capital. Proceedings of the National Academy of Sciences of United States of America. 114 (48), 12720-12724.

3. Beker, G., (1975), Human Capital: A theoretical and empirical analysis with special references to education. University of Chicago Press, SUA.

4. Bugge, M.M., Hansen, T., Klitkou, A., (2016), What is bioeconomy? A review of the literature. Sustainability. 8 (1), 1-22.

5. Chen, P., Ibbotson, R.G., Milevsky, M.A., Zhu, C.X., (2006), Human Capital, Asset Allocation, and Life Insurance. Financial Analysts Journal. 62 (1), 97-109.

6. Čiutienè, R., and Railaitè, R., (2015), A development of human capital in the context of an aging population. 20th International Scientific Conference Economics and Management. Procedia - Social and Behavioral Sciences. 2013, 753 - 757.

7. Clark, T.S., and Linzer, D.A., (2012), Should I use fixed or random effects?. http://polmeth.wustl.edu/files/polmeth/clarklinzerrefemar2012.pdf> (Accessed 27 February 2019).

8. Coleman S. J., (1988), Social capital in the creation of human capital. The American Journal of Sociology. 94, 95-120.

9. D'Amato, D., Droste, N., Allen, B., Kettunen, M., Lahtinen K., Korhonen, J., Leskinen, P., Matthies, B.D., Toppinen, A., (2017), Green, circular, bioeconomy: A comparative analysis of sustainability avenues. Journal of Cleaner Production. 168, 716-734.

10. European Commission, (2011), A roadmap for moving to a competitive low carbon economy in 2050. Brussels.

11. European Commisssion, (2012), Bioeconomy Strategy. "Innovating for Sustainable Growth: a Bio-economy for Europe". Brussels.

12. Goldin, C., (2016), Human capital. Handbook of Cliometrics. Heidelberg, Germany: Springer Verlag.

13. Hilgartner, S., (2007), Making the bioeconomy measurable: Politics of an emerging anticipatory machinery. Biosocieties. 2, 382-386.

14. Hsiao, C., (2002), Analysis of Panel Data, New York: Cambridge University Press.

15. International Risk Governance Council (IRGC), (2008), Risk Governance Guidelines for Bioenergy Policies. International Risk Governance Council, Geneva, Switzerland.

S sciendo Studia Universitatis "Vasile Goldis" Arad. Economics Series Vol 29 Issue 1/2019 
Neagu, O., Dumiter, F., Braica, A., Jimon, Ş., David, G. (2019)

The correlation between human capital and gross added value in the bioeconomy sectors at the European Union (EU) country level

16. Ipate, N., David, K.D., Ipate, I., Bogdan, A., (2015), The bioeconomy model in future sustenable development. Studia Universitatis "Vasile Goldiş", Economic Series. 25 (2), 115-123.

17. Kleinschmit, D., Linsdstad, B. H., Thorsen, B. J., Toppinen, A., Ross, A., Baarden, S., (2014), Shades of green: A social scientific view on bioeconomy in the forest sector. Scandinavian Journal of Forest Reseach. 29 (4), 402-410.

18. Kucharčíková, A., and Mičiak, M., (2017), Human Capital Management in Transport Enterprise. MATEC Web of Conferences. 134, 1-8.

19. Lafuente, E., Rabetino, R., (2011), Human capital and growth in Romanian small firms. Journal of Small Business and Enterprise Development. 18 (1), 74-96.

20. Leliaert, P.J.C., Candries W., Tilmans T., (2003), Indentifying and managing IC: a new classification. Journal of Intellectual Capital. 4 (2), 201-2014.

21. Li, H., Loyalka, P., Scott, R., Wu, B., (2017), Human capital and China's future growth. Journal of Economic Perspectives. 31 (1), 25-48.

22. Luthans, F., Luthans, K.W. and Luthans, B.C., (2004), Positive psychological capital: beyond human and social capital. Business Horizons. 47, 44-50.

23. Massingham, P.R., Tam, L., (2015), The relationship between human capital, value creation and employee reward. Journal of intellectual capital. 16 (2), 390-418.

24. Mazza, L., Ten Brink, P., (2012), Supporting briefing-Green economy in the European Union. UNEP. Available at: https://ieep.eu/uploads/articles/attachments/071ec7ac$3 \mathrm{e} 08-4 \mathrm{~d} 92-8 \mathrm{~b} 26-$

45a2254489c3/KNOSSOS_Green_Economy_Supporting_Briefing.pdf?v=636645097 83

25. M'Barek, R., Philippidis, G., Suta, C., Vinyes, C., Caivano, A., Ferrari, E., Ronzon, T., Sanjuan Lopez, A., Santini, F., (2014), Observing and analysing the bioeconomy in the EU-adapting data and tools to new questions and challenges. Bio-based and Applied Economics. 3 (1), 83-91.

26. McCormick, K., Kautto, N., (2013), The bioeconomy in Europe: An overview. Sustainability. 5, 2589-2608.

27. Mincer, J., (1958), Investment in human capital and personal income distribution. Journal of Political Economy. 66, 281-302.

28. Neagu, O., (2012), Measuring the effects of the human capital on growth in the case of Romania. Annals of "Dunărea de Jos" University. 1, pp.83-92.

29. Nelson R., Winter, S., (1982), An evolutionary theory of economic change. Cambridge, MA: Belknap Press.

30. OECD, Eurostat, WHO (2011). A System of Health Accounts 2011. OECD Publishing.

31. Ollikainen, M., (2014), Forestry in bioeconomy - Smart green growth for the humankind. Scandinavian Journal of Forest Research. 29 (4), 360-366.

32. Padel, S., Niggli, U., Pearce, B., Schlüter, M., Schmid, O., Cuoco, E., Willer, E., Huber, M., Halberg, N., Micheloni, C., (2010), Implementation Action Plan for Organic Food and Farming Research. Technology Platform Organics, IFOAM EU Group. 
Neagu, O., Dumiter, F., Braica, A., Jimon, S., David, G. (2019)

The correlation between human capital and gross added value in the bioeconomy sectors at the European Union (EU) country level

33. Pfau, S.F., Hagens, J.E., Dankbaar, B., Smits, A.J.M., (2014), Visions of sustainability in bioeconomy research. Sustainability. 6 (3), 1222-1249.

34. Pribac, L., and Anghelina, A., (2015), Human capital - The effects of education on economic growth within the European Union. Studia Universitatis "Vasile Goldiș", Economic Series. 25 (3), 35-44.

35. Ronzon, T., Piotrowski, S., M'Barek, R., Carus, M., (2017), A systematic approach to understanding and quantifying the EU's bioeconomy. Bio-based and Applied Economics. 6 (1), 1-17.

36. Roth, S., (2017), Air pollution, educational achievements, and human capital formation. IZA World of Labor. 381, 1-10.

37. Scarlat, N., Dallemand, J.F., Monforti-Ferrario, F., Nita, V., (2015), The role of biomass and bioenergy in future bioeconomy: Policies and facts. Enviromental Development. 15, 3-34.

38. Schmid, O., Padel, S., Levidow, L., (2012), The bio-economy concept and knowledge base in a public goods and farmer perspective. Bio-based and Applied Economics. 1 (1), 47-63.

39. Schultz, T.W., (1961), Investment in human capital. American Economic Review. 51, $1-17$.

40. Smith, A., (1776), An inquiry into the nature and causes of the wealth of nations. Oxford University Press.

41. Szekacs, A., (2017), Enviromental and ecological aspects in the overall assessment of bioeconomy. Journal of Agricultural and Environmental Ethics. 30 (1), 153-170.

42. Ten Pierick, E., van Mil, E.M., Meeusen, M.J.G., (2010), Transition towards a biobased economy-In the biobased economy: biofuels, materials and chemicals in the post-oil era. Langeveld, J.W., Sanders, J.P.M., Meeusen, M., Eds. Earthscan: London, UK. 18-32.

43. Tomer, J., (1999), The human firm: A socio-economic analysis of its behavior and potential in a new economic age, New York: Routlege.

44. World Economic Forum, (2018), Towards a reskilling revolution: A future of jobs for all. Available:http://www3.weforum.org/docs/WEF_FOW_Reskilling_Revolution.pdf

\section{Appendix}

A. Tests for equation 1 ( 26 countries)

1. Heteroskedasticity accross panels

. xtgls GVA Empl, panels(hetero)

Cross-sectional time-series FGLS regression

Coefficients: generalized least squares

Panels: heteroskedastic

Correlation: no autocorrelation

Estimated covariances $=26 \quad$ Number of obs $=156$

Estimated autocorrelations $=0 \quad$ Number of groups $=26$ 
Neagu, O., Dumiter, F., Braica, A., Jimon, S., David, G. (2019)

The correlation between human capital and gross added value in the bioeconomy sectors at the European Union (EU) country level

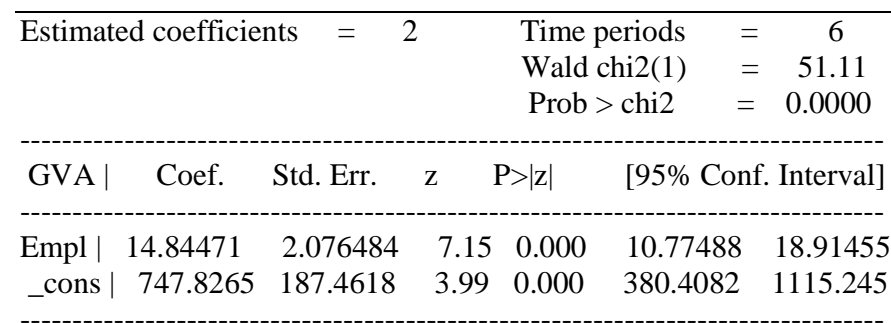

\section{Correlation accross panels (cross sectional correlation)}

. xtgls GVA Empl, panels(correlated)

Cross-sectional time-series FGLS regression

Coefficients: generalized least squares

Panels: heteroskedastic with cross-sectional correlation

Correlation: no autocorrelation

$\begin{array}{lrrrr}\text { Estimated covariances }= & 351 & & \text { Number of obs }= & 156 \\ \text { Estimated autocorrelations }= & 0 & \text { Number of groups }= & 26 \\ \text { Estimated coefficients }= & 2 & \text { Time periods }=6 \\ & & \text { Wald chi2(1) }=640.97 \\ & \text { Prob }>\text { chi2 }=0.0000\end{array}$

\begin{tabular}{|c|c|c|c|c|c|}
\hline GVA & Coef. & Std. Err. & $\mathrm{z}$ & $\mathrm{P}>|\mathrm{z}|$ & [95\% Conf. Interval] \\
\hline Empl | & 15.97587 & .6310241 & 25.32 & 0.000 & 14.73908 \\
\hline cons & 1427.746 & 348.3169 & 4.10 & 0.000 & 745.0571 \\
\hline
\end{tabular}

Note: when the number of panels is greater than or equal to the number of periods, results are based on a generalized inverse of a singular matrix.

Note: you estimated at least as many quantities as you have observations.

\section{Autocorrelations of errors within panels}

. xtgls GVA Empl, panels(hetero) corr(independent)

Cross-sectional time-series FGLS regression

Coefficients: generalized least squares

Panels: heteroskedastic

Correlation: no autocorrelation

Estimated covariances $=26 \quad$ Number of obs $=156$

Estimated autocorrelations $=0 \quad$ Number of groups $=26$

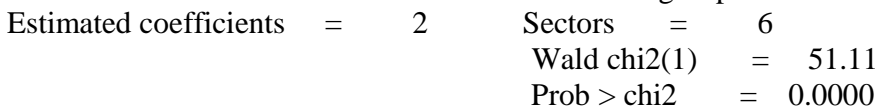

GVA $\mid \begin{array}{lll}\text { Coef. Std. Err. } & \mathrm{z} & \mathrm{P}>|\mathrm{z}| \\ \text { [95\% Conf. Interval] }\end{array}$


Neagu, O., Dumiter, F., Braica, A., Jimon, S., David, G. (2019)

The correlation between human capital and gross added value in the bioeconomy sectors at the European Union (EU) country level

\begin{tabular}{c|cccccc} 
Empl| & 14.84471 & 2.076484 & 7.15 & 0.000 & 10.77488 & 18.91455 \\
_cons | & 747.8265 & 187.4618 & 3.99 & 0.000 & 380.4082 & 1115.245
\end{tabular}

.xtgls GVA Empl, panels(hetero) corr(ar1)

Cross-sectional time-series FGLS regression

Coefficients: generalized least squares

Panels: heteroskedastic

Correlation: common AR(1) coefficient for all panels (0.2906)

Estimated covariances $=26$ Number of obs $=156$

Estimated autocorrelations $=1 \quad$ Number of groups $=26$

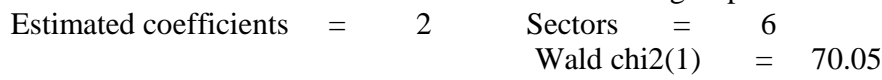

Prob $>$ chi $2=0.0000$

\begin{tabular}{|c|c|c|c|c|c|c|}
\hline GVA | & Coef. & Std. Err. & $\mathrm{z}$ & $\mathrm{P}>|\mathrm{z}|$ & [95\% Conf. & Interval] \\
\hline Empl | & 15.77937 & 1.885281 & 8.37 & 0.000 & 12.08429 & 19.47445 \\
\hline _cons | & 438.6295 & 191.9815 & 2.28 & 0.022 & 62.35263 & 814.9063 \\
\hline
\end{tabular}

. xtgls GVA Empl, panels(hetero) corr(psar1)

Cross-sectional time-series FGLS regression

Coefficients: generalized least squares

Panels: heteroskedastic

Correlation: panel-specific $\mathrm{AR}(1)$

Estimated covariances $=26 \quad$ Number of obs $=156$

Estimated autocorrelations $=26 \quad$ Number of groups $=26$

Estimated coefficients $=2$ Sectors $=6$

Wald chi2(1) $=306.00$

Prob $>$ chi $2=0.0000$

\begin{tabular}{|c|c|c|c|c|c|c|}
\hline GVA | & Coef. & Std. Err. & $\mathrm{z}$ & $\mathrm{P}>|\mathrm{z}|$ & [95\% Conf. & Interval] \\
\hline Empl | & 16.82222 & .961666 & 17.49 & 0.000 & 14.93739 & 18.70705 \\
\hline _cons | & 1422.233 & 235.8799 & 6.03 & 0.000 & 959.9171 & 1884.549 \\
\hline
\end{tabular}

. xtgls GVA Empl, panels(iid) corr(psar1)

Cross-sectional time-series FGLS regression

Coefficients: generalized least squares

Panels: homoskedastic

Correlation: panel-specific $\mathrm{AR}(1)$

Estimated covariances $=1 \quad$ Number of obs $=156$

Estimated autocorrelations $=26 \quad$ Number of groups $=26$ 
Neagu, O., Dumiter, F., Braica, A., Jimon, S., David, G. (2019)

The correlation between human capital and gross added value in the bioeconomy sectors at the European Union (EU) country level

\begin{tabular}{lll}
\hline Estimated coefficients $=2$ & Sectors $=6$ \\
& Wald chi2(1) $=64.14$ \\
& Prob $>$ chi2 $=0.0000$
\end{tabular}

\begin{tabular}{|c|c|c|c|c|}
\hline GVA & Coef. Std. Err. & $\mathrm{P}>|\mathrm{z}|$ & $\%$ Conf. Int & rval] \\
\hline Empl | & 14.97996 & 0.000 & 11.31386 & 18.64 \\
\hline _cons | & 2951.623 & 0.000 & 1722.024 & 4181 \\
\hline
\end{tabular}

\section{B. Tests for equation 1 (15 high developed European countries)}

\section{Heteroskedasticity across panels}

. xtgls GVA Empl, panels(hetero)

Cross-sectional time-series FGLS regression

Coefficients: generalized least squares

Panels: heteroskedastic

Correlation: no autocorrelation

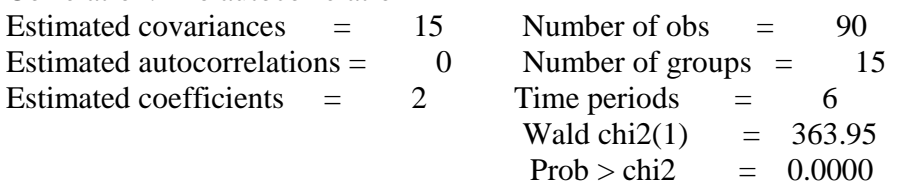

\begin{tabular}{|c|c|c|c|c|c|}
\hline GVA | & Coef. & Std. Err. & $\mathrm{z}$ & $\mathrm{P}>|\mathrm{z}|$ & [95\% Conf. Interval] \\
\hline Empl | & $\begin{array}{r}43.4199 \\
2498940\end{array}$ & $\begin{array}{r}2.275992 \\
181521\end{array}$ & 19.08 & 0.000 & $\begin{array}{rr}38.95903 & 47.88076 \\
-1058796 & 6056695\end{array}$ \\
\hline
\end{tabular}

\section{Correlation across panels (cross-sectional correlation)}

.xtgls GVA Empl, panels(correlated)

Cross-sectional time-series FGLS regression

Coefficients: generalized least squares

Panels: heteroskedastic with cross-sectional correlation

Correlation: no autocorrelation

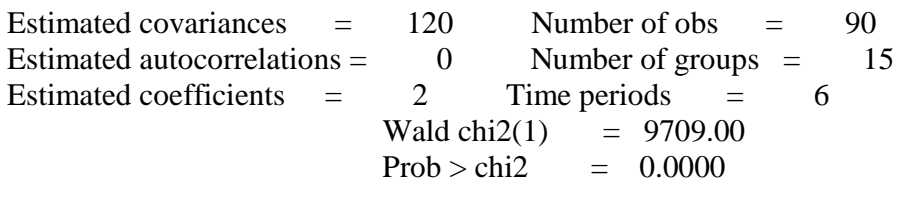

\begin{tabular}{|c|c|c|c|c|c|}
\hline GVA & Coef. & Std. Err. & $\mathrm{z}$ & $\mathrm{P}>|\mathrm{z}|$ & [95\% Conf. Interval] \\
\hline Empl | & 43.95834 & .4461224 & 98.53 & 0.000 & $43.08396 \quad 44.83273$ \\
\hline _cons | & 446.7039 & 106.1651 & 4.21 & 0.000 & $238.6241 \quad 654.7836$ \\
\hline
\end{tabular}


Neagu, O., Dumiter, F., Braica, A., Jimon, S., David, G. (2019)

The correlation between human capital and gross added value in the bioeconomy sectors at the European Union (EU) country level

Note: when the number of panels is greater than or equal to the number of periods, results are based on a generalized inverse of a singular matrix.

Note: you estimated at least as many quantities as you have observations.

\section{Autocorrelation of errors within panels}

. xtgls GVA Empl, panels(hetero) corr(independent)

Cross-sectional time-series FGLS regression

Coefficients: generalized least squares

Panels: heteroskedastic

Correlation: no autocorrelation

Estimated covariances $=15 \quad$ Number of obs $=90$

Estimated autocorrelations $=0 \quad$ Number of groups $=15$

Estimated coefficients $=2$ Time periods $=6$

Wald chi2(1) $=363.95$

Prob $>$ chi $2=0.0000$

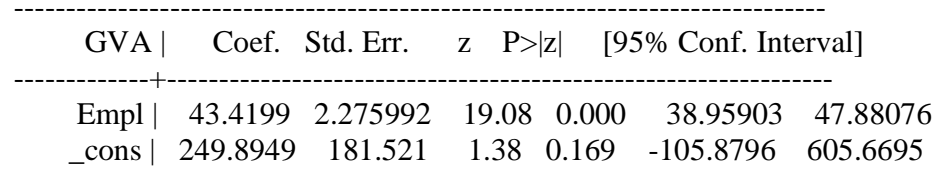

. xtgls GVA Empl, panels(hetero) corr(ar1)

Cross-sectional time-series FGLS regression

Coefficients: generalized least squares

Panels: heteroskedastic

Correlation: common AR(1) coefficient for all panels (-0.0190)

Estimated covariances $=15 \quad$ Number of obs $=90$

Estimated autocorrelations $=1 \quad$ Number of groups $=15$

Estimated coefficients $=2$ Time periods $=6$

Wald chi2(1) $=364.17$

Prob $>$ chi $2=0.0000$

\begin{tabular}{|c|c|c|c|c|c|c|}
\hline GVA | & Coef. & Std. Err. & $\mathrm{P}>\mid \mathrm{z}$ & {$[95$} & $5 \%$ Conf. Int & rrval] \\
\hline & & & 19.08 & 0.000 & & \\
\hline _cons | & 266.3549 & 182.0022 & 1.46 & 0.143 & -90.36282 & 623.0727 \\
\hline
\end{tabular}

. xtgls GVA Empl, panels(hetero) corr(psar1)

Cross-sectional time-series FGLS regression

Coefficients: generalized least squares

Panels: heteroskedastic

Correlation: panel-specific AR(1)

Estimated covariances $=15 \quad$ Number of obs $=90$

Estimated autocorrelations $=15 \quad$ Number of groups $=15$

Estimated coefficients $=2$ Time periods $=6$ 
Neagu, O., Dumiter, F., Braica, A., Jimon, S., David, G. (2019)

The correlation between human capital and gross added value in the bioeconomy sectors at the European Union (EU) country level

$$
\begin{array}{lll}
\text { Wald chi2(1) } & = & 344.00 \\
\text { Prob }>\text { chi } 2 & = & 0.0000
\end{array}
$$

\begin{tabular}{|c|c|c|c|c|c|}
\hline GVA | & Coef. & Std. Err. & $\mathrm{P}>|\mathrm{z}|$ & $\%$ Conf. Inter & erval] \\
\hline Empl| & 42.02453 & 32.265814 & 18.550 .000 & 37.58361 & 46.46544 \\
\hline _cons | & 621.2271 & 195.132 & $3.18 \quad 0.001$ & 238.7754 & 1003.679 \\
\hline
\end{tabular}

. xtgls GVA Empl, panel(iid) corr(psar1)

Cross-sectional time-series FGLS regression

Coefficients: generalized least squares

Panels: homoskedastic

Correlation: panel-specific $\operatorname{AR}(1)$

Estimated covariances $=1$

Estimated autocorrelations $=15$

Estimated coefficients $=2$

Number of obs $=90$

Number of groups $=15$

\begin{tabular}{|c|c|c|c|c|c|c|}
\hline GVA | & Coef. & Std. Err. & $\mathrm{z}$ & $\mathrm{P}>|\mathrm{z}|$ & [95\% Conf. & Interval] \\
\hline Empl| & 43.23727 & 2.343818 & 18.45 & 0.000 & 38.64347 & 47.83107 \\
\hline _cons | & 809.5885 & 510.2686 & 1.59 & 0.113 & -190.5195 & 1809.697 \\
\hline
\end{tabular}

$\begin{array}{rlc}\text { Time periods } & = & 6 \\ \text { Wald chi2(1) } & = & 340.31 \\ \text { Prob }>\text { chi2 } & = & 0.0000\end{array}$

